\title{
[原 著]
}

\section{内陸部中都市 ( $\mathrm{T}$ 市) における地域騒音 に関する調查研究}

——第 3 報 学校に設置された防音壁の遮音効果の検討ならびに 既設新幹線・高速自動車道周辺地域の騒音伝播状況について——

$$
\text { 平木陽 一* }
$$

\section{Studies on Community Noise in a Japanese Inland Middle-sized City}

3. Survey of Effect of Sound-proof Walls in Schools and on Noise Propagation from the Super-express Railways Shinkansen and Automobile Express Way

\section{Yohichi HIRAKI*}

The sound-proof walls established in two elementary schools of $\mathrm{T}$ City were surveied for their soud-insulating effect. Also noise propagation was investigated along the superexpress railways Shinkansen and an automobile express way to seek its effect on the regional environment. The results were as follows :

1) The measured values of some points of traffic noise were compared with the values on the noise decrement curve against distance, which was theoretically obtained by taking, as the sound level of source, the measurement at a point close to the traffic sound source, on the assumption that the traffic noise has a linear sound source. The measurements in the two schools only partly approximated the theoretically obtained values on the decrement curve, but were closely similar to the measured values alongside the Shinkansen and automobile express way.

2) The sound-insulating effects of the sound-proof walls in the two elementary schools were estimated by comparison with the noise measurement at a control site. The walls were found to diminish the railroad noise only by $5-10 \mathrm{~dB}$, and in the school house with windows opened, the noise level was $66 \mathrm{~dB}$ at the min., and $84 \mathrm{~dB}$ at the Max.. Some kinds of train fairly impulsively emitted noise, which lasted about 30 seconds during the passing

* 群馬大学医学部公衆衛生学教室 (主任 : 辻 達彦教授)

* Department of Public Health, School of Medicine, Gumma University (Director: Prof. Tatsuhiko Tsuji) 
of the train. This occurred at about $12 \mathrm{~min}$. intervals on the average, and was consequently assumed to affect learning efficiency. In a school beside a traffic road, which is a cutting road, the sound-proof wall up on the mural side of the road was appreciably effective in arresting sound.

3) The prospective effects of noises of the Shinkansen and automobile express way on the regional environment of $\mathrm{T}$ city were estimated from the results of survey on the vicinity of the existing ones. Noise in the residential quarters on both sides of the Shinkansen within the range of $300 \mathrm{~m}$ from the railroad (exclusive of bustling streets near the station) was estimated at about $70 \mathrm{~dB}$. On both sides of the automobile express way within $100 \mathrm{~m}$ from it, the noise is estimated to fluctuate by about $10 \mathrm{~dB}$, and within $400 \mathrm{~m}$, noise of about $50 \mathrm{~dB}$ will be constantly present with a slight variation.

\section{はじめに}

T市の騷音環境の主体は道路交通騒音であり, それによって地域住民の日常生活 や学校に拈ける 学習活動に大きな影響がもたらされていることは 第 $1 \cdot 2$ 報1から明らかである.

公害対策の基本が発生源対策にあることは自明 であり, T市の騒音問題でいうならば，車輛機 構, 道路構造の改善がそれに相当する.しかし, それらの早急な解決は期待し得ないのが現状であ りまた，道路周辺環境整備による騒音伝播対策 も既成市域にあっては十分な施策を望み得ない。 従って, 残された方法の一つとしては家屋構造, 付帯施設による受音過程での遮音・吸音性の補強 があげられる。

現在，T市に打いて具体的な遮音設備が施され ている学校は, 防音壁を設置した 2 小学校と, 校 舎の道路側の空を 2 重化した高校の計 3 校があ る. 2 重空による遮音効果については，既に前報 で触れたので，本報では 2 小学校の防音壁の遮音 効果について検討した。すなわち，これらを一つ の事例とし今後の騒音対策を考える上での資料を 求めようとするものである.

一方，騒音対策を考学る上で，音源の実態を知 ることは欠かせないことである．この面から， T 市内を貫通して新設される新幹線・高速自動車道 通過予定地域 2) と地形的に類似した立地条件をも
つ, 既設新幹線 (東海道・山陽) - 高速自動車道 （東北）沿線を選び, 騒音の伝播状況の測定を行 った。得られた成績をもとに，これらの新施設が T市の地域環境条件に及ぼす影響について考察し た成績も併せて報告する次第である。

\section{I 調 查研究の方法}

\section{1 騒音測定方法}

1) 防音壁のある学校の場合

防音壁の設置されている 2 小学校（国鉄信越線 近接校および主要国道 17 号線隣接校) に执いて, 軌道または国道の走行線に対し直角線上に测定点 数力所を定めた.

それらの各測定点に和いて, 指示騒音計 (リオ ソK.K, NA-09型) に自動記録計 (リオンK.K, LR-03 型, Paper Speed: $3 \mathrm{~mm} / \mathrm{sec}$, pen speed : slow）を接続し, 聴感補正回路はA 特性で騒音レ ベルの測定を行った・測定に際し, 集音マイクロ ホンはすべて地上（または床上） $1.2 \mathrm{~m}$ の高さと し，風ならびに振動による影響を除外するように した。

湘定 (記録) 時間は, 列車騒音については列車 通過時間とし，その間にみられた各測定点での騒 音ピーク・レベルをとって検討資料とした。道路 交通騒音では15 分間連続測定した記録紙上から， その時間内の最も平均的騒音レベルを示している と考党られる時間帯をとり，5秒間隔で 50 回の記 
録值から $90 \%$ レンジの中央值ならびに上・下限值 を求めた。測定は鉄道近接校は昭和 51 年 9 月, 国 道隣接校は 52 年 3 月の晴天日の午前 10 時〜午後 3 時に行った。

2）既設新幹線・高速自動車道周辺の騒音

(1)新幹線について

神奈川県藤沢市地内の東海道新幹線高架（高さ $8 \mathrm{~m}$ ）付近で, 地形のやや異った 2 力所之兵庫県 明石市魚住町地内の山陽新幹線高架 (高さ $10 \mathrm{~m}$ ) 付近丘陵地形 1 力所, 計 3 地点に和いて新幹線騒 音の伝播状況を測定した. 上記測定地点の選 定 は, T市に和ける新幹線通過予定地の地形之類似 していることを条件としたが，T市通過予定地域 は市街地であるが，測定対象地域は田園丘陵地带 である。

(2)高速自動車道について

東北自動車道の通過する群馬県館林市白旗地内
でコンクリート製スレート板防音壁のある地点 と, 防音壁のない地点で騒音伝播状況を調 查し た. 测定対象の高速自動車道（以下，高速 道と 略）は, 高さ $6 \mathrm{~m}$ の盛土式 4 車線道路で，周辺は 田園地带であり，T市貫通予定の地帯に類似する 地点である。また，都心からの距離は約 $100 \mathrm{~km}$ で あり， T市との地理的状況 および高速道と接続す る道路状況，インターチェンジなどの条件も似た 地内である.

騒音測定条件は, 新幹線, 高速道ともに, 軌道 または道路の走行線に対し 直角線上に定めた 3 4 点で同時に測定した。使用した騷音計，自動記 録計および測定方法は，全て全項同様である.な 拈測定は東海道新幹線の場合は昭和 49 年 3 月, 山 陽新幹線は 48 年 12 月, 東北自動車道は 52 年 4 月の 晴天日の午前 10 時〜午後 3 時の間に行った.

2 防音壁の遮音効果ならびに 新幹線・高速道
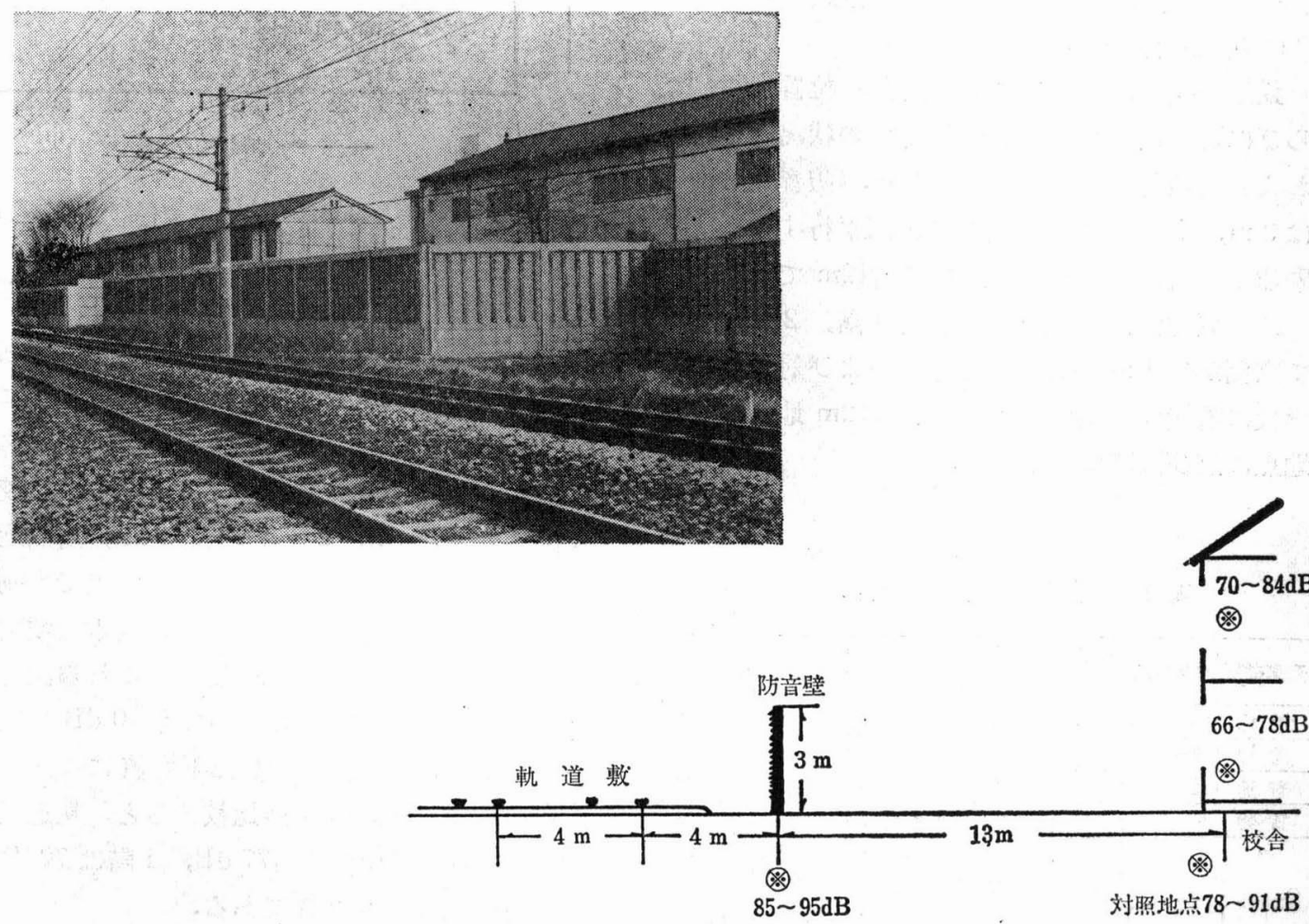

写真 1・付図 鉄道と測定点（校舎）の関係（騒音ピーク・レペル 刚楖定点） 
騒音の伝播状況の評価の方法

音の伝播過程に扣ける音源からの距離による減 衰則にもとずき，各測定点の騒音レベルを計算に よって求めた。用いた計算式は線音源の場合は (1) 式を，点音源の場合は(2)式を用いた ${ }^{32}$ 。

$$
\begin{aligned}
& \mathrm{L}_{(1)}=\mathrm{PWL}-8-10 \log _{10} 1(\mathrm{~dB}) \\
& \mathrm{L}_{(2)}=\mathrm{PWL}-11-20 \log _{10} \mathrm{l}(\mathrm{dB})
\end{aligned}
$$

〔註〕 $\mathrm{L}$ ：音源から $1(\mathrm{~m})$ の距離の点での騒音 レベル $(\mathrm{dB})$

PWL : 音源パワーレベル

但し，音源のパワーレベルは実際上は不明なの で, 音源に最も近い測定点での実測平均值を基準 に，上記計算式から推定した。

以上の方法によって得られた音源からの距離に よる理論上（計算値）の騒音レベル（以下，傾向 線による值と称す）と実測值とを比較した。

\section{III成樍ならびに検討}

1 防音壁の遮音効果

\section{(1)鉄道騒音}

鉄道近接校に和ける軌道己校舎の位置的関係な らびに防音壁（コンクリート製）の状況は写真 1 およびその付図に示す通りである。防音壁の高さ は $3 \mathrm{~m}$ ，校舎は軌道に対してほぼ平行する木造 2 階建で，軌道敷端からの距離は約 $12 \mathrm{~m}$ である。

騒音測定は，軌道敷端と校舎 1 階，2 階に打い て窓側から $1 \mathrm{~m}$ 内側の廊下床上および対照として 学校に隣接する畑で軌道敷端から $12 \mathrm{~m}$ 地点を対照 地点に選び同時に測定した。

\begin{tabular}{|c|c|c|c|c|c|c|}
\hline \multirow{2}{*}{ 列車程類 } & \multirow{2}{*}{ 車轌編成 } & \multirow{2}{*}{$\begin{array}{c}\text { 測定数 } \\
\mathrm{n} \\
\end{array}$} & \multicolumn{4}{|c|}{ 騒音ピークレベル範囲 $(\mathrm{dB})$} \\
\hline & & & 軌道敷地端 & 校舎 1 階 & 校舎 2 階 & 対照地点 \\
\hline 特急 & $10 \sim 12$ 輛 & 7 & $85 \sim 95$ & $68 \sim 75$ & $70-84$ & $79 \sim 84$ \\
\hline 急 行 & $7 \sim 10$ & 5 & $89 \sim 94$ & $69 \sim 74$ & $76 \sim 80$ & $78 \sim 83$ \\
\hline 普通 & $3 \sim 6$ & 8 & $86 \sim 95$ & $66 \sim 78$ & $71 \sim 81$ & $79 \sim 84$ \\
\hline 貨物 & $30 \sim 33$ & 4 & $89 \sim 91$ & $67 \sim 76$ & $71 \sim 81$ & $89 \sim 91$ \\
\hline & t & 24 & $\begin{array}{c}\text { 䇥囲 } 85 \sim 95 \\
\bar{X} \quad 90.2 \\
S D \pm 2.45\end{array}$ & $\begin{array}{c}66 \sim 78 \\
72.5 \\
\pm 4.01 \\
\end{array}$ & $\begin{array}{c}70 \sim 84 \\
77.2 \\
\pm 3.12 \\
\end{array}$ & $\begin{array}{c}78 \sim 91 \\
81.2 \\
\pm 2.57\end{array}$ \\
\hline
\end{tabular}

表 1 防音壁内・外側の騒音レベル
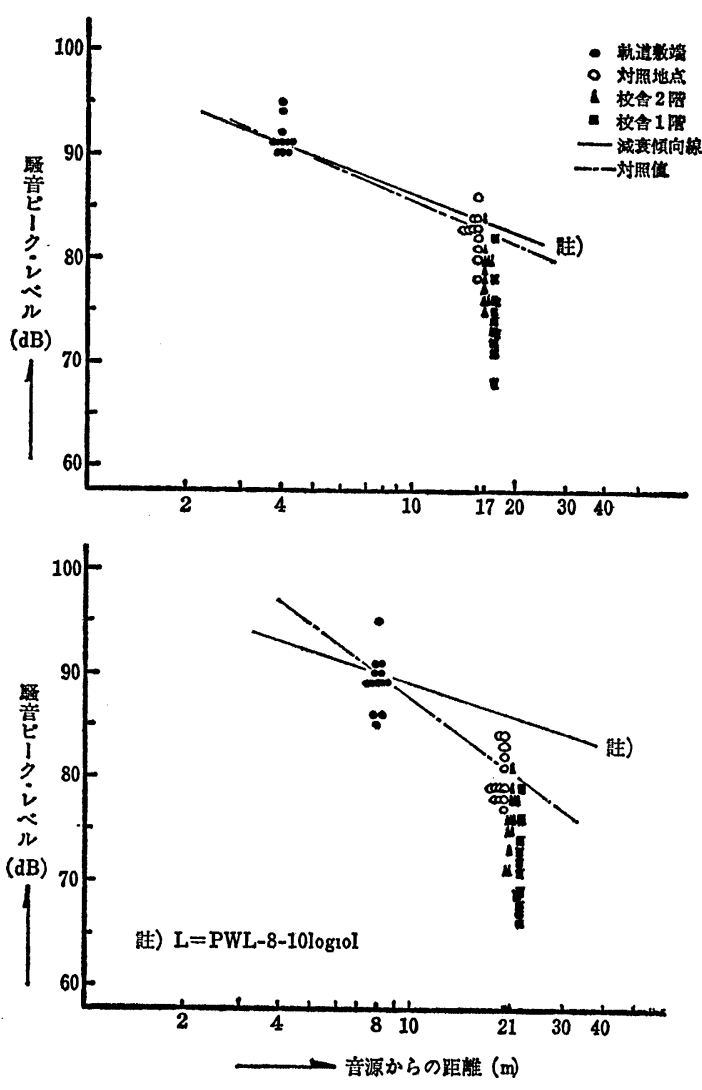

図 1 音源からの距離による理論傾向線と実測值

午前 10 時から午後 3 時をでの 5 時間に通過した 上・下線の列車種類別の各測定点に护ける騒音ピ ーク・レベルを表 1 に示した。騒音発生源に最も 近い軌道敷端における列車通過時騒音ピーク・レ ベルは 85 95 dB.の範囲にある. 同様に, 校舎内 1 階で66〜 78 dB， 2 階で $70 \sim 84 \mathrm{~dB}$, 対照地点で は78 91 dB のごとく, 何れの測定点でも測定值 に $10 \mathrm{~dB}$ 前後の幅がみられるが，列車種類別によ って大きな相違は認められない。これら測定値の 変動幅が何れの測定点においても $10 \mathrm{~dB}$ 程度であ ることから，表下段に示した平均值によって各測 定点のピーク・レベルを比較すると, 軌道敷端の $90 \mathrm{~dB}$ に対して校舎 2 階 $77 \mathrm{~dB}, 1$ 階は $72 \mathrm{~dB}$ であ り, 対照地点は $81 \mathrm{~dB}$ である.

図 1 は, 音源に最も近い軌道敷端の測定平均值 
を基点として求めた距離による騒音隇衰傾向線お よび各測定別，列車別の実測值を示したものであ る.この際, 下り線と軌道敷端の距離は $4 \mathrm{~m}$, 上 り線とは $8 \mathrm{~m}$ である。

音源と測定点の間に，障害物のない対照地点に おける実測值と減衰傾向線による值を比べると き, 下り線の場合は, 減衰傾向線値と実測值は近 似した推移を示しているが，上り線では明らかに 相違している.

このことから，傾向線と実測值とを比較して， 防音壁の遮音効果を評価することは不適当と考光 られるので, 対照地点と校舎内 (開空時) におけ る測定值との比較から遮音効果を推定した.

下り線の場合, 対照地点の騒音ピーク・レベル の平均值は $83 \mathrm{~dB}$ に対し, 校舎 1 階で $74 \mathrm{~dB}, 2$ 階 は79 dBで，その差は $9 \mathrm{~dB}$ と $\mathrm{dB}$ である.また， 上り線の場合, 対照地点の $81 \mathrm{~dB}$ に対し, 1 階71 $\mathrm{dB}, 2$ 階 $76 \mathrm{~dB}$ であるから，とれぞれ $10 \mathrm{~dB} ， 5 \mathrm{~dB}$ の差がみられる・これらの差が防音壁の遮音効果 ということができょう・なお，この場合，校舎 2 階に拈ける遮音効果が低いのは防音壁の高さが十 分でなく, 2 階の上部分が, 音源に対して露出状 態になっていることによる (写真 1 参照).

一方, 校舎に到達する騒音レベルでみるならぱ 最低 $66 \mathrm{~dB}$ ( 1 階), 最高 $84 \mathrm{~dB}$ (2 階) の高值で あり，騒音の少ない環境を得る目的からみるなら ば, 防音壁の実質的効果は弱いものといわざるを 得ない.

図 2 は, 列車編成で最も車輛数の多い貨物列車 (33輌編成) と最も少ない普通列車（3輛編成） についての各測定点に和ける騒音記録状況を示す ものである. 図から，列車騒音が，かなり衝撃的 に波及することが推定されるとともに，その影響 時間は貨物列車の場合，約 30 秒間にわたってい る.さらに, 測定時間中, 通過列車数は上・下線 合せて24列車であって, 約 12 分毎に 1 列車が通過 することになり，その都度，授業が一時中断さ れ，授業妨害はかなり大きなるのであることが解 る.

2）国道騷音

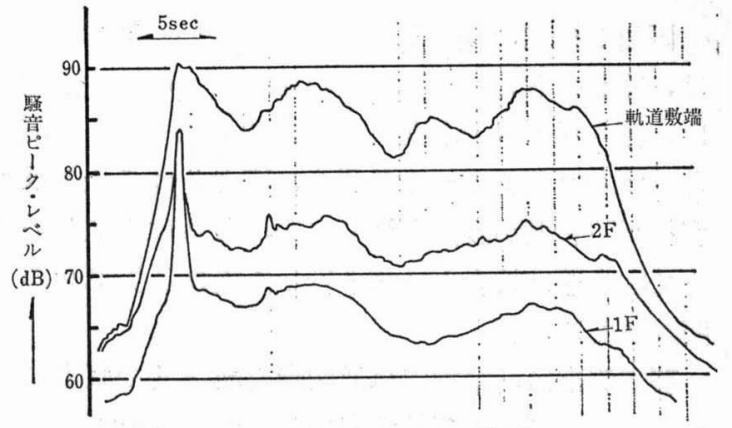

（上り）货物列車. 33 䊔絀成

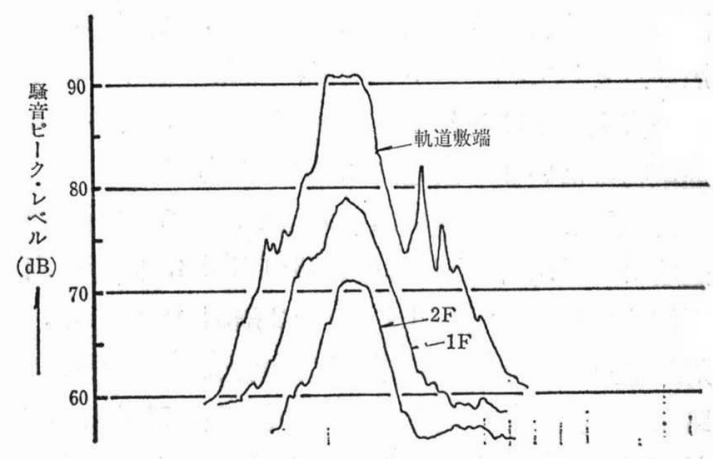

（下り）普通列車・ 3 灀絀成

図 2 列車通過時の騒音: (各記録紙から合成)
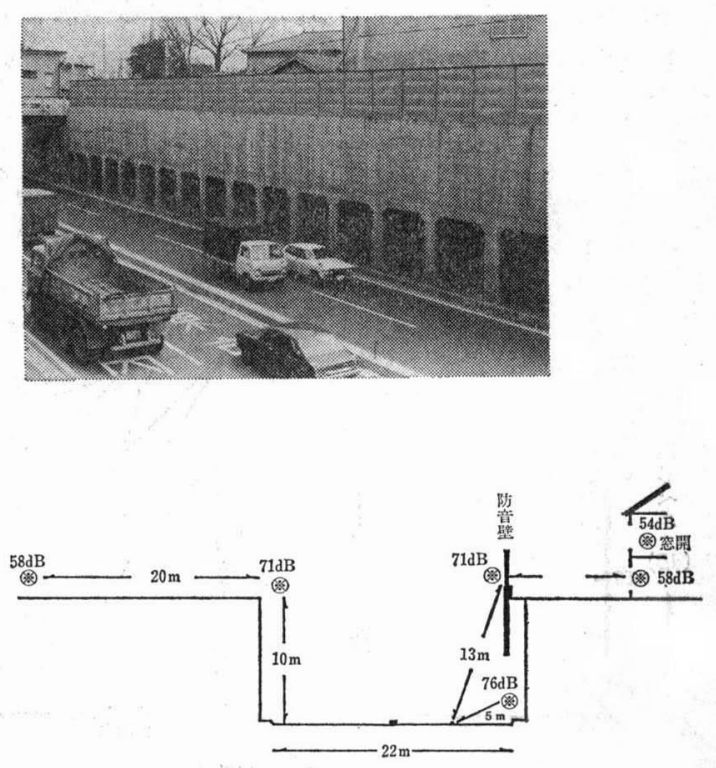

写真 $2 \cdot$ 付図 堀割内道路と測定点 （騒音レベル中央值田印測定点） 
国道の構造，防音壁ならびに校舎の距離的状況 は，写真 2 およびその付図の通りである。校地 は, 深さ $10 \mathrm{~m} 4$ 車線堀割内国道の壁上で接し, 高 さ $1 \mathrm{~m}$ のコンクリート基礎上に高さ $3 \mathrm{~m}$ の金属吸 音板製防音壁が設置されている・校舎は木造 2 階 建で防音壁は校舎とほぼ平行して校舎より $10 \mathrm{~m}$ の 距離にある。

騒音測定は，堀割内車道側歩道端とその直上の 防音壁道路側および校地内で防音壁より $10 \mathrm{~m}$ 地点 と校舎 2 階道路側空から $1 \mathrm{~m}$ の床上（測定時, 空 開放)の 4 測定点で同時に記録した。ささらに，対 照地点として堀割道路を隔て，学校の対岸になる 堀割直上およびそれより $20 \mathrm{~m}$ 奥まった，その間に 遮蔽物のない住居敷地内に抒いて測定した。

得られた騒音レベルは中央值で, 堀割内道路歩 道端で76 dB, 直上防音壁道路側 $71 \mathrm{~dB}$, 防音壁内 側校地内 $10 \mathrm{~m}$ 地点 $58 \mathrm{~dB}$, 校舎 2 階 $54 \mathrm{~dB}$ である. 対照地点とした国道対岸の堀割直上および $20 \mathrm{~m}$ 道 路側より奥まった地点では，それぞれ $71 \mathrm{~dB}, 58$ dBであり，その值は，防音壁道路側および校地の 防音壁より内側 $10 \mathrm{~m}$ 地点の場合と同值である.

困 3 は，各測定点の騒音レベルの中央值，上・ 下限值について，音源からの距離による推移を示 したものである・図に示した堀割内道路歩道端を

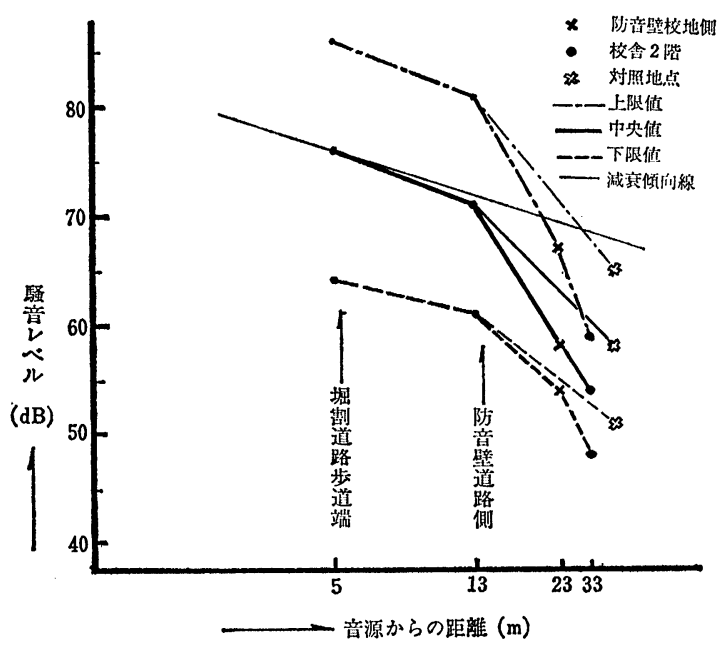

図 3 堀割国道騒音の距離による理論減衰線と実測值
基点として求めた距離による 騒音減衰傾向線は, 堀割直上の実測值と $1 \mathrm{~dB}$ の差である.これは， 一般的に堀割構造の場合は，道路および壁面の反 射性を考慮し，計算值から $2 \mathrm{~dB}$ だけ割引くこと とされている4)ので，実測值と騒音減衰 傾 向 線 は，ほぼ一致していることになる。

一方，堀割対岸に設定した対照地点の実測值を 距離による騒音減衰傾向線值 と比べるとき，実測 值の $58 \mathrm{~dB}$ は減衰傾向線值より $10 \mathrm{~dB}$ 低值となって いる.このことは，音の伝播過程において堀割構 造によって，生じた音の迂回による遮音効果と考 えられる・これに対し, 防音壁内側校地内 $10 \mathrm{~m}$ 地 点の実測值が対照地点 $(20 \mathrm{~m})$ と同值であること は，伝播距離として $10 \mathrm{~m}$ 分の減衰が防音壁によっ て得られたものと推定される・校舎 2 階では，さ らに $4 \mathrm{~dB}$ 低值となっている. その結果，堀割道 路内発生騒音は，校舎内に 拈いて授業を妨げない 低值に減衰し，防音壁設備を施した目的を果して いる。

\section{2 既設新幹線騒音}

騒音測定した新幹線沿線 3 地内の地形の概略と 各地内に設置した測定点の音源（新幹線高架）か らの距離は，図4 の通りである.A地内は高架か ら約 $30 \mathrm{~m}$ 附近まで乾田で，それょり高さ $6 \mathrm{~m}$ の丘
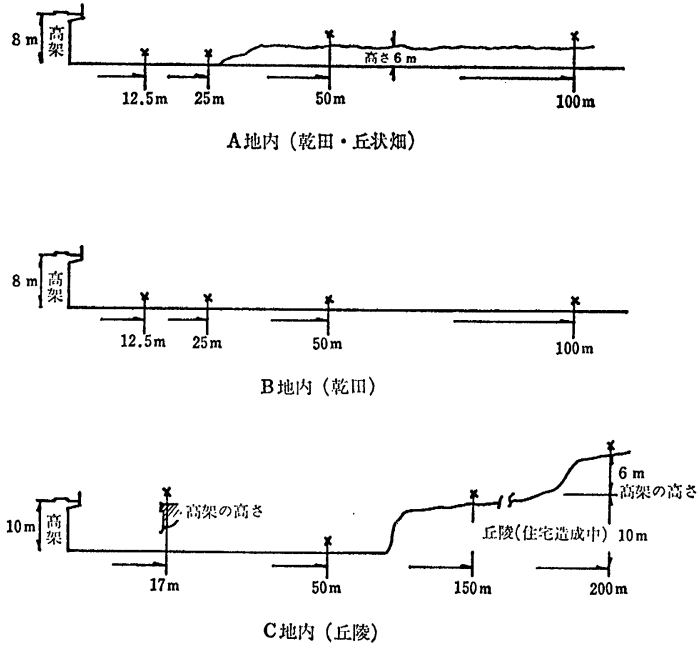

図 4 既設新幹線沿線における測定点と地形 
状地形の畑になる地形であり， B 地内は測定点が ほぼ水平状に乾田が続いている.C地内の場合は， 丘陵地形に和ける騒音の伝播状況を調査する目的 から土地を選んだことにより測定点は必ずしも直 線上に設置できなかった。 以上の 3 地内とれぞれ 4 測定点に扔いて, 列車通過時騒音を同時に測定 した・な括，測定対象列車は，すべて測定側の軌 道を走行する列車とし, 列車速度は一定の目標点 を各列車の編成全車軣 $(400 \mathrm{~m})$ が通過する時間を 計ることによって算出した。

得られた全測定点の騒音ピーク・レベルおよび 平均值 $(\bar{X})$ と標準偏差 (SD) は表 2 に示した. 全体的にみて, 何れの測定点に预いても列車毎の 騒音ピーク・レベルの差は小さく, 変動幅は 1 $2 \mathrm{~dB}$ である. 従って, 各測定点の騒音ピーク・ レベルの平均值によって, 音源から各測定点まで の距離による騒音の減衰傾向をみたのが図 5 , 図 6 である. 図中に示した前項同様に求めた理論上 の減衰傾向線と実測值を比較すると, A ・ B 2 地 内では傾向線と実測值がほぼー一致することがみら

表 2 各測定点の騒音ピーク・レベル（単位 $\mathrm{dB}$ )

\begin{tabular}{|c|c|c|c|c|}
\hline \multirow{8}{*}{$\begin{array}{c}\text { A 地 区 } \\
\text { (乾田·丘状) }\end{array}$} & \multicolumn{4}{|c|}{ 高架橋中心線（垂直下）からの距離 } \\
\hline & \multirow{2}{*}{$\frac{12.5 \mathrm{~m} \text { 地点 }}{89}$} & \multirow{2}{*}{$\frac{25 \mathrm{~m} \text { 地点 }}{90}$} & \multirow{2}{*}{$\frac{50 \mathrm{~m} \text { 地点 }}{86}$} & \multirow{2}{*}{$\frac{100 \mathrm{~m} \text { 地点 }}{81}$} \\
\hline & & & & \\
\hline & 88 & 88 & 83 & 80 \\
\hline & 87 & 88 & 84 & 79 \\
\hline & 90 & 91 & 86 & 82 \\
\hline & 88 & 89 & 86 & 82 \\
\hline & 88 & 89 & 85 & 82 \\
\hline \multirow{3}{*}{$\begin{array}{c}\bar{X} \\
\text { SD }\end{array}$} & $\underline{88.3}$ & 89.2 & 85.0 & $\underline{80.8}$ \\
\hline & \pm 1.03 & $\pm \underline{1.17}$ & \pm 1.26 & $\pm \underline{1.17}$ \\
\hline & 87 & 89 & 87 & 81 \\
\hline \multirow{3}{*}{$\begin{array}{l}\text { B 地 区 } \\
\text { (乾田) }\end{array}$} & 87 & 88 & 86 & 80 \\
\hline & 87 & 88 & 87 & 81 \\
\hline & 89 & 90 & 89 & 83 \\
\hline \multirow{2}{*}{$\begin{array}{l}\bar{X} \\
\text { D D }\end{array}$} & 87.5 & 88.8 & 87.2 & $\underline{81.2}$ \\
\hline & $\pm \underline{1.00}$ & $\pm \underline{0.96}$. & \pm 1.26 & \pm 1.26 \\
\hline \multirow{4}{*}{$\begin{array}{l}C \text { 地 区 } \\
\text { (丘陵) }\end{array}$} & $17 \mathrm{~m}$ 地点 & $50 \mathrm{~m}$ 地点 & $150 \mathrm{~m}$ 地点 & $200 \mathrm{~m}$ 地点 \\
\hline & 80 & 68 & 63 & 68 \\
\hline & 80 & 67 & 62 & 68 \\
\hline & 82 & 69 & 64 & 70 \\
\hline \multirow{2}{*}{$\underset{\text { S D }}{\bar{X}}$} & 80.7 & 68.0 & 63.0 & 68.7 \\
\hline & \pm 1.15 & \pm 1.00 & \pm 1.00 & \pm 1.15 \\
\hline
\end{tabular}

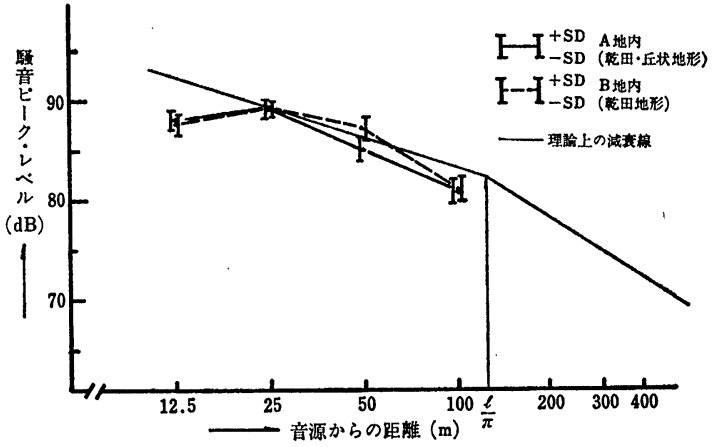

図 5 既設新幹線騒音の測定值と距離減衰 (A・B 地内)

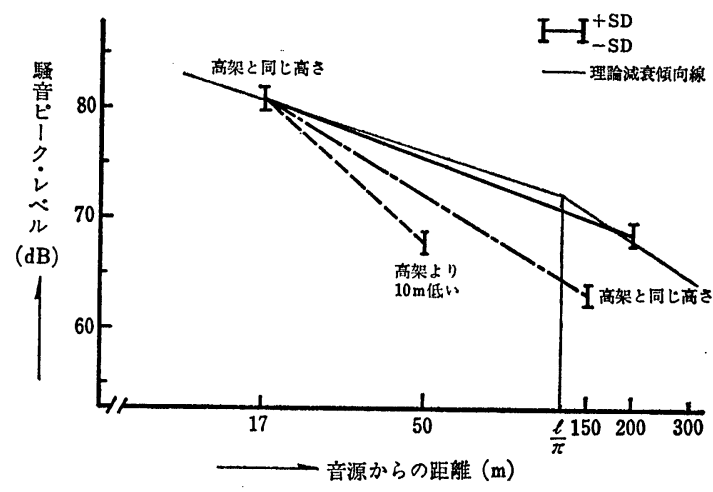

図 6 既設新幹線騒音の測定值と距離隇衰 (C地内)
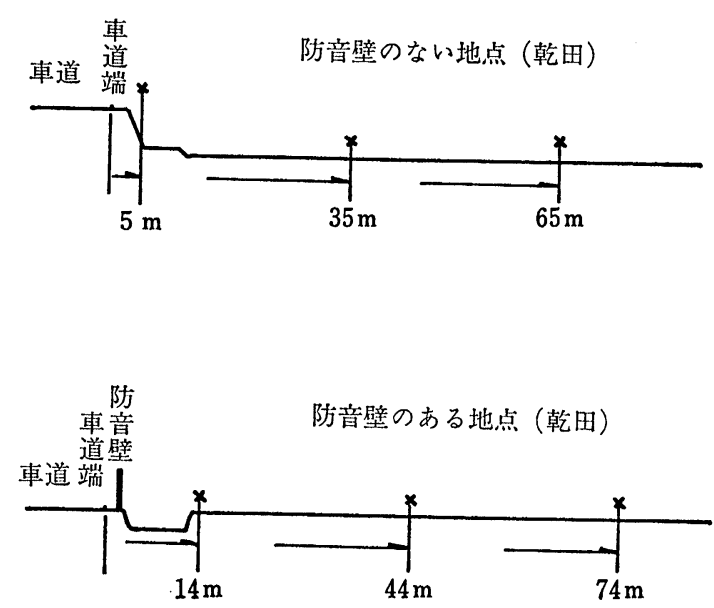

図 7 既設高速自動車道における測定点と地形 
表 3 各測定点の騷音レベル（単位 $\mathrm{dB}$ )

\begin{tabular}{c||c|c|c}
\hline \multicolumn{1}{c||}{$\begin{array}{c}\text { 剆定点道路 } \\
\text { 端よ }\end{array}$} & \multicolumn{3}{|c}{ 防音壁のない地点 } \\
\cline { 2 - 4 } 測定番号 & $5 \mathrm{~m}$ & $35 \mathrm{~m}$ & $65 \mathrm{~m}$ \\
\hline \hline 1 & $68(57-85)$ & $64(55-73)$ & $60(52-68)$ \\
2 & $67(58-79)$ & $60(53-67)$ & $57(53-64)$ \\
3 & $70(59-80)$ & $62(52-70)$ & $59(52-67)$ \\
4 & $68(59-83)$ & $60(53-71)$ & $57(52-66)$ \\
5 & $71(55-81)$ & $61(54-70)$ & $59(53-67)$ \\
\hline \hline $\bar{X}$ & $68.8(57.6-81.6)$ & $61.4(53.4-70.2)$ & $58.4(52.4-66.4)$ \\
\cline { 2 - 4 } $\mathrm{SD}$ & $1.64(1.67-2.41)$ & $1.67(1.14-2.17)$ & $1.34(1.65-1.52)$ \\
\hline
\end{tabular}

\begin{tabular}{|c|c|c|c|}
\hline \multirow{2}{*}{$\begin{array}{c}\text { 唰定点道路 } \\
\text { 端より } \\
\text { 娜定番号 } \\
\end{array}$} & \multicolumn{3}{|c|}{ 防音壁のある地点 } \\
\hline & $14 \mathrm{~m}$ & $44 \mathrm{~m}$ & $74 \mathrm{~m}$ \\
\hline \multirow[t]{5}{*}{1} & $62(56-67)$ & $59(53-65)$ & $58(54-63)$ \\
\hline & $63(58-69)$ & $60(55-63)$ & $59(53-64)$ \\
\hline & $62(53--68)$ & $59(53-64)$ & $58(54-63)$ \\
\hline & $64(60-68)$ & $62(55-66)$ & $60(55-65)$ \\
\hline & $62(57-68)$ & $60(55-64)$ & $59(55-62)$ \\
\hline \multirow{2}{*}{$\begin{array}{c}\bar{X} \\
\text { S D } \\
\end{array}$} & $62.6(56.8-68.0)$ & $60.0(54.2-64.4)$ & $58.8(54.2-63.4)$ \\
\hline & $0.89(2.59-0.71)$ & $1.23(1.10-1.14)$ & $0.86(1.84-1.14)$ \\
\hline
\end{tabular}

れる・しかしながら，C地内（図6）では音源か ら最長距離にある丘陵地形上の $200 \mathrm{~m}$ 地点の実測 值は傾向線とは一致するが，それ以外の測定点で は, 傾向線に対して実測值が約 $10 \mathrm{~dB}$ 程度低值と なっている・

このことは, 複雑な地形以外の処では, 発生源 を線音源と見做して騒音の減衰則によって求めた 傾向線から，新幹線による騒音の伝播状況の推定 が可能なことを示していると考兄られる.

\section{3 既設高速自動車道騒音}

東北自動車道騒音の測定地内 の地形と測定距離 は図 7 のごとくで, 各測定点の 騷音レベルを表 3 に示した。防音壁のない地点の場合, 騒音レベル の中央值は道路端 $5 \mathrm{~m}$ で $67 \sim 71 \mathrm{~dB}$ であり，それ に対し， 65m 離れた地点での騒音レベルは57〜60 $\mathrm{dB}$ 範囲で，この間で約 $10 \mathrm{~dB}$ の減少がみられた ことになる，同様なことを上限值でみると，道路 端 $5 \mathrm{~m}$ での最高值 $85 \mathrm{~dB}, 65 \mathrm{~m}$ 地点での最高值 68 $\mathrm{dB}$ で約 $17 \mathrm{~dB}$ の減衰量がみられた。それに対し て，防音壁のある地点では，道路端から $14 \mathrm{~m}$ 地 点では 62〜 $64 \mathrm{~dB}$ を示し，それょり $60 \mathrm{~m}$ 離れた 74 $\mathrm{m}$ 地点では58〜 $60 \mathrm{~dB}$ となり, その間約 $4 \mathrm{~dB}$ の減

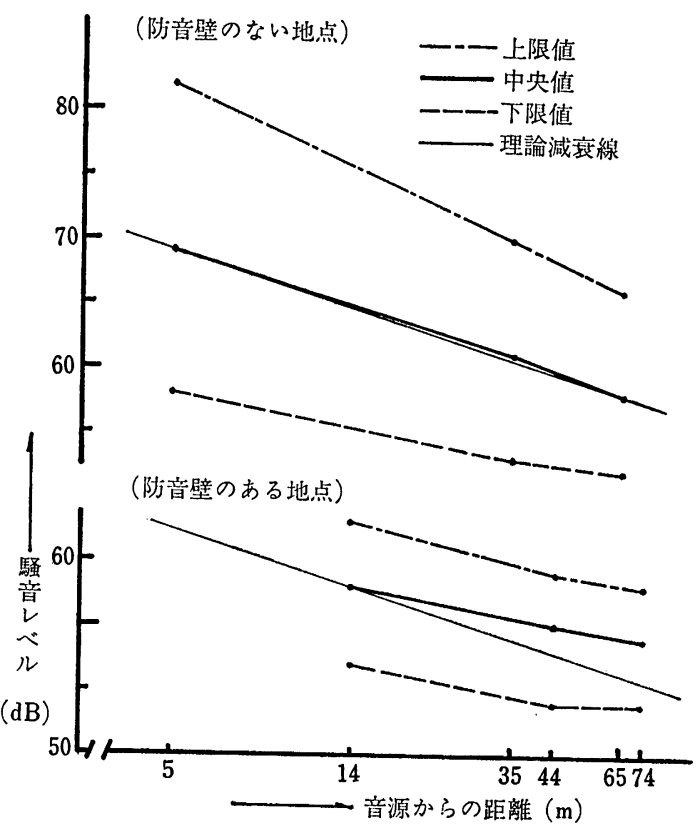

図 8 既設高速自動車道騒音の測定值と距離減衰 （東北自動車道）

衰しかみられない。上限值の場合も同様に $14 \mathrm{~m}$ 地 点 $69 \mathrm{~dB}, 74 \mathrm{~m}$ 地点で $65 \mathrm{~dB}$ と減衰量は少ない。

図 8 は，防音壁のない地点とある地点の各測定 点の道路端からの距離と騒音レベルの中央值打よ び上・下限值の実測值の推移を，距離による減衰 傾向線と比較したものである．防音壁のない地点 での騒音レベル中央值は，傾向線とほ注一致した 減衰を示しているが，防音壁のある地点での中央 值は，傾向線よりも高い騒音レベル（減衰量，少） にあることがみられる・また，上・下限值の距離 による傾向線は，音源からの距離が增すに従い， 中央值に近づく傾向がみられる。従って, 遮蔽物 のない地内に和いては，傾向線から推定するなら ば道路から 400mの範囲をで, 変動の少ない $50 \mathrm{~dB}$ 前後の騒音が常在する様な状況が生ずることが考 えられる。

4 地域騒音環境に及ぼす影響について

新幹線, 高速道の T市内通過予定線の概略は図 9 のごとくであり，新幹線は約 $11.3 \mathrm{~km}$ にわたっ て，高さ $8 \sim 11 \mathrm{~m}$ の高架で，市内を通過する. 図 


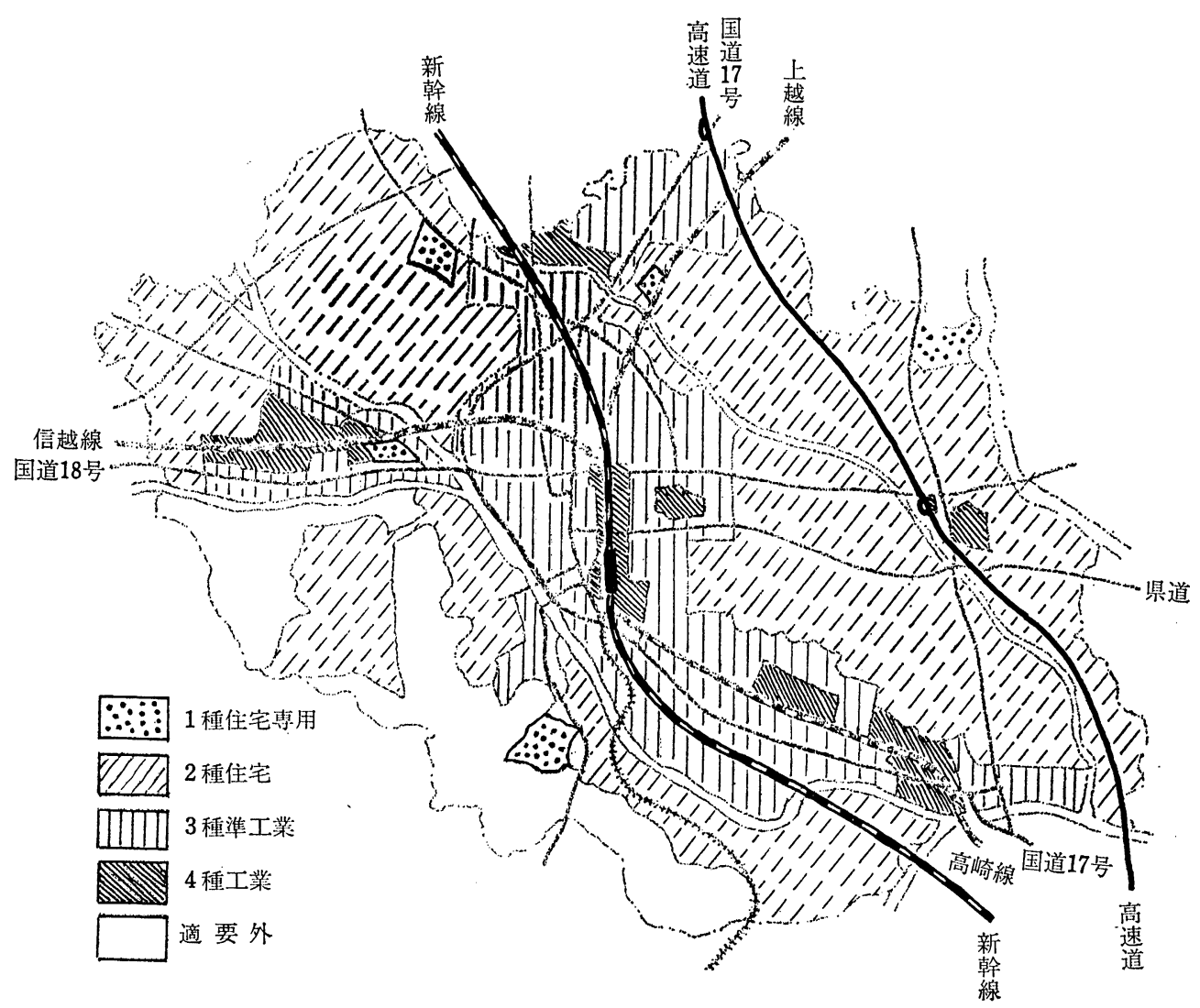

図 9 新幹線・高速道通過予定線と騷音規制区域図

中に示した騒音規制区域5)からみるならば，その ほとんどは準工商区域である。そこに所在する家 屋は，店舗兼住家屋が大部分を占め，その他は在 来住居が殆どであり，比較的人口密度の高い地域 である.この地域の昼間時の 騒音レベル中央值で みると, 在来駅周辺の繁華街は $60 \mathrm{~dB}$ を超え, こ れ以外の地域は最高 $52 \mathrm{~dB}$ 最低 $48 \mathrm{~dB}$ の範囲にあ る(第 1 報).

前項で調查した新幹線騒音の 伝播状況からみる ならば，騒音を遮蔽する 周辺環境条件がない地域 の場合は，沿線両側約 $300 \mathrm{~m}$ 筙囲で70dB を超える 騒音環境が出現すると考兄られる。しかし，実際 には高層建造物が集中する在来線駅を中心とする 地带では，現在の地域騒音も比較的大.さいことと 併せて，新幹線騒音による影響は相対的に少ない
ものとなろう・けれども，その他の地域では，既 設新幹線にみられる防音壁と同程度の防音設備で あるならば，新幹線騒音と地域騒音との差が 10 $\mathrm{dB}$ 前後生ずる地带が出現し, 人口密度も高いこと から，その影響は大きいことが推定される。

一方，高速道の通過予定地域は，T市の東南部 の田園地带を, 高さ $6 \sim 8 \mathrm{~m}$ の盛土式 4 車線道路 で, 全長約 $11.2 \mathrm{~km}$ に及ぶ.これらの地域は， T 市としても人口密度の低い地域であり, 現状に和 いては被害人口は少ないことが推定される.

乙かしながら，東京に比較的近い地理的条件か ら，都内交通規制との関連で，大型貨物車の走行 が夜間中心となることが推定される。このこと は, 高速道周辺地域にみられる住宅急增傾向と併 せて考えるならば，現段階からの十分なる防音設 
備を考慮する必要性が明らかである。

\section{III 考按}

自動車による道路騒音や列車による鉄道騒音な ぞのいわゆる地表輸送機関騒音は，音源が身近か にあることから，環境問題のなかでも社会的関心 の高いものである・地表輸送機関によって生ずる 被害は, 騒音に限らず振動についても考光なけれ ばならないし，自動車の場合は，排気ガスによる 大気污染もまた深刻な問題である。それらに対す る対策は, 緒言で述べたごとく発生源対策が基本 となることは自明であるが，音源対策がこの面に おいて最も遅れていることは明らかである.

T市では, 地域騒音によって学習活動の妨害を 受けている学校が相当な割合で存在するが，それ らの中で外部騷音に対する防音設備が設置されて いるのは被害が酷い 2 校のみである.しかしなが ら, 現在すすめられている地域開発に伴い遅かれ 早かれ防音設備を必要とする学校が多数生ずるこ とは，第 2 報の成績からも明らかである・本報で は, その様な観点から, 現在設置されている防音 壁について，その設備が本来の目的を十分に果し ているか否かを確めた。一方, 既設新幹線高速自 動車道騒音の伝播状況を調查し，得られた成績を もとに，近くT市を貫通して建設されるこれらの 新施設からの騒音が，T市の地域騒音環境に及ぼ す影響について検討を加光，今後の施策に対する 資料提供を企てた。

騒音の伝播過程での減衰は, 音源と受音点との 間に障害物のないとき，音波は幾何学的拡散によ って, 音源から遠さかる程, 受音点での音の強さ は小さくなることが知られている ${ }^{3)}$.この場合, 地面が平坦で反射性の場合は，野外飞招いてもほ ぼ理論上の法則に従うとされている6). このこと から, 調査対象について, 音源と測定点（受音 点）との距離による理論上の.騒音減衰傾向線を求 め，その值と実測值とを比較することによって， 評価, 検討の目安を得ることを計画した。

しかしながら，2 小学校における妨音壁の遮音 効果については，予め用意した対照地点に和ける
実測值と理論上の騒音減衰傾向線とは, 必ずしも 一致しない成績であった。従って, 対照地点の実 測值と校舎内の実測值を比較することによって, 全体的な騒音減衰量を推定する方法をとったこと から, 防音壁の遮音効果について, 詳細な検討を なしうるまでに至らなかった。

校舎に到達する騒音レベルからみるならば，鉄 道近接校に和いては最低 $66 \mathrm{~dB}$ ( 1 階), 最高 $84 \mathrm{~dB}$ （2 階）の高值であった。しかも，かなり衝撃的 に波及し,また約 30 秒にもわたる騒音が, 単純平均 すると約 12 分間に 1 回の割合で出現していた。こ のよ5な断続的騒音の授業に及ぼす影響について は, 大場ら》による次の実験成績がある. $1 \mathrm{KHz}$ $80 \mathrm{~dB}$ の 3 秒 ON- 3 秒 OFF と 3 秒 ON- 1 秒 OFFの 2 種の断続騒音を児童に負荷するとき，生理的評 価で 3 秒一 3 秒の方が影響は大きく，知的作業評 価では異った間隔の断続音間に有意差は認められ なかったと報告している、また，詫間8)は，騒音 レベルの変動幅の大きい程, 阻害的影響の度合は 大きくなるであろう・と述べている・これらのこ とから，心理的な影響や一時的な授業中断等の状 況が生じ, 学習能率に対する影響の大きいことが らかがわれる。これに比べ国道隣接校の場合は, 校舎内に到達する騒音は空開放時 $90 \%$ レンジ中央 值の最高值で $54 \mathrm{~dB}$ 前後であり, 学習環境として 騒音の影響は無視しうる程度のものであった。こ のことは隣接する国道を堀割道路構造にしたこと と，その壁直上に施した防音壁とによって，かな りの効果がみられた事例といえよう.

騒音源を音の透過しにくい物体によって遮蔽す る手段は，ごく一般的な方法であり，新幹線，高 速自動車道に和いても広く利用されていることは 周知である.しかしながら，それによってどの程 度の効果が得られているか，となると，とくに新 幹線の場合は，これまで多くの調查研究成績9) 12) にみられるごとく, 沿線地域住民の生活妨害は, かなり深刻なものがあり，十分な効果が得られて いないことは明らかである。

柴田 ${ }^{13)}$ は高梘・岡山両市内住民, 約 2,400 人の アンケート調査から, 新幹線騒音による被害の波 
及について次のごとく要約している。

1）新幹線音を騒音として感ずる人は，線路に 近いものほど多く, $10 \mathrm{~m}$ 以内で $90 \%$, 以後, 距離 によって漸減するが，100〜200mで，60\%，200m 以上離れていても30\%近くの人が「うるさい」と 答えている.

2 ）木造，鉄筋，モルタル等の建物構造による 騒音の感じ方に差はみられない。それは，日本の 夏型天候に対して空を明けた生活と関連する。

3 ）居住家屋と新幹線の間に 建物がある場合, 騒音による被害は，間に建物がない場合に比べ若 干減少する・騒音に対する苦情は単に線路からの 距離に逆比例するのではなく，騒音レペルに比例 することを示している.これらの5ち，2），3) は，まことに当然であると感ずる一方で，新幹線 騒音を考皇るとき見落してはならない部分を示し ていると考学れる。

本報の調查成績において 距離別受音点の実測騒 音レベルと距離による理論上の隇衰傾向線值が一 致した。しかし，これをもって，新幹線通過予定 地を中心に距離別周辺地区の騒音レベルの将来予 測をすることは慎重でなければならないことは当 然である. 岩本ら ${ }^{14)}$ は, 例苀ば，昼間の暗騒音が 55 60 dB ある地域では, 5 るささの程度や生活 妨害の訴党が $50 \%$ 以あり，そこに64〜 76 dB の 新幹線が開業しても, 開業前に比べ開業後の訴兄 率は増さないが, 暗騒音 $40 \mathrm{~dB}$ 前後の地域では, うるささや生活妨害が明らかに大きく生じたこと を報告している，すなわち，新しく騒音源となっ た新幹線騒音の影響は，これまでにあった暗騒音 の高低によって異なって表れることを示す成績で あり，下市の場合もそのことを考慮しなければな らない。

新幹線の生活環境に及ぼす影響は, 騒音と同時 に振動があることは明らかである。これについて は，本報では直接的調査は実施していないが，柴 田は前述の調查 ${ }^{15)}$ に扔いて騒音に対する苦情と振 動に対する苦情の割合は，新幹線からの距離でみ るとき全く一致していることを述べている。すな わち, 騒音と振動の被害を同時に受けているのが
実態であろう.このことから，受音過程に㧊いて 遮音設備のみを設置しても対策としては不十分な ことが推測される。

一方, 高速自動車道騒音の場合は, 変動幅の大 きい騒音の影響は, 比較的狭い地域範囲に留り, 90\%レンジの上・下限值の間に $10 \mathrm{~dB}$ 内外の差が 出現するのは, 平坦地形で道路から $100 \mathrm{~m}$ 以内と 推定された。しかし，それより $400 \mathrm{~m}$ 範囲までは 変動幅の小さい $50 \mathrm{~dB}$ 前後の騒音が常在すること が考えられる.それは，第 1 報の成績から推測す るならば，その範囲に居住する住民の $55 \%$ 前後は， 騒音に対する苦情をむつことが推定される。さ らに，通過予定地域の現在の夜間に打ける暗騒音 は,かなり低值であるのに対し, 開通後は大型貨 物車の夜間走行が予想される. 相沢ら ${ }^{16)}$ の深夜騒 音の影響についての調查によれば，一般国道 4 車 線道路に标いて中央值 $66 \mathrm{~dB}$, 上・下限值 $77 \mathrm{~dB}$, $54 \mathrm{~dB}$ の地域住民の被害訴えは50\%に達するとの ことであり，一部地域に打いて，この程度の生活 妨害の発生は当然予測される処である.

T市の地域騒音環境の影響が大きいことは，第 1・2 報の通りである.これに加えて 新幹線高速 自動車道の貫通が，T市の環境条件をさらに悪化 させることは十分に予測される処である。それに 対し，本報で検討した現有の防音壁の遮音効果か らみるならば，実質的効果は弱いといわざるを得 ない. 従って騒音発生源に対する騒音の拡散防止 上から，発生源近接位置に和ける吸音，遮蔽対策 の強化が必須である。㐬た，騒音規制に関する再 検討によって，環境保全の強力な施策が望まれ る.

\section{ま と め}

T市の 2 小学校に設置された防音壁の遮音効果 について検討したままた，既設新幹線，高速自動 車道沿線に和いて, 騒音の伝播状況について調查 を行い，地域騒音環境に及洔す影響について考察 した. 得られた所見は以下のごとくである.

1）交通騒音を線音源と見做し，各測定の音源 に近接する実測值を基点とした理論上の距離によ 
る騒音減衰傾向線值と測定点の実測值を比べた。 2 小学校における実測值と理論上の傾向線とは一 部で近似するのみであったが，既設新幹線高速自 動車道騒音の実測值とは近似していた。

2） 2 小学校の防音壁の遮音効果は, 対照地点の 実測值との比較から推定したが，鉄道騒音に対す る防音壁の遮音効果は, 僅かに $5 \sim 10 \mathrm{~dB}$ の減少 に留り, 空開放校舎内の騒音レベルは最低 $66 \mathrm{~dB}$, 最高 $84 \mathrm{~dB}$ の高值となっていた・通過する列車の 種類によっては，かなり衝撃的に波及する騒音， 約30秒にわたる通過騒音が，単純平均で約 12分間 毎に出現し，学習能率に影響を及ぼしていること が推定された。国道隣接校は，堀割道路構造でそ の壁上の防音壁によって，かなりの遮音効果がみ られた。

3 ）新幹線・高速自動車道沿線に拈ける騒音の 伝播状況を調查し，T市の地域騒音環境に及ぼす 影響について推察した。新幹線騒音は予定沿線下 両側 $300 \mathrm{~m}$ 範囲の住居地域 (駅周辺繁華街地域を 除く)では, $70 \mathrm{~dB}$ 前後の騒音環境の出現が推定さ れた・高速自動車道騷音の影響は，道路両側 100 $\mathrm{m}$ 範囲は, 変動幅 $10 \mathrm{~dB}$ 前後の騷音が現われ, 400 $\mathrm{m}$ 範囲では $50 \mathrm{~dB}$ 前後の変動幅の小さい騒音が常 在することが予測された。

最後に本研究にあたり御指導と御校閲を戴いた过 達彦教授, 終始御根篤なる御指導, 御援助を戴いた永 田稔助教授並びと非常勤講師箕輪真一博士飞深甚なる 謝意を表し,さらと御協力戴いた教室員各位飞感謝申 し上げます。

\section{文献}

1) 平木陽一：内陸部中都市（T市）飞拈ける地域騒音 飞関する調查研究, 第 1 報 地域の構造による騒音特
性と住民反応, 第 2 報 地域騒音の学校に及ほす影 響, 民族衛生, 42(5)，236-248（1976）

2）高崎市：公害対策の概要 昭和 51 年版

3）産業公害防止協会編：騒音防止技術, 小宮山出版, 71-86 (1976)

4 ）金泉 昭：道路交通騒音の伝播対策，公害と対策, 11 (12), 32-33 (1975)

5 ) 群馬県: 高崎市騒音規制区域図, 昭和 47 年群馬県告 示第108号, 昭和 47 年 4 月 1 日施行

6）金泉 昭：4）と同じ，27-28

7 ）大島義夫, 他：騒音が児童生徒の学習能率飞及ぼす 影響江関する実験的研究 (第 1 報), 第21回 日本学校 保健学会講演集, 401（1975）

8 ）詫間晋平：レベル変動幅を考虑した騒音水準の表示 (騒音不快指数) 亿関する基磷的研究, 学校保健研究, 13(11), 502-505 (1971)

9）仙台市：新幹線鉄道騒音の実態拉よびその理論的考 察, 仙台市衛生局（1972）

10）村松常司, 他：新幹線騒音, 振動等の健康飞及ほす 影響飞関する研究 (第 1 報), 日本公衛誌, 23 (8), 471-481 (1976)

11）平松幸二, 他：新幹線騒音招よび模擬騒音のうるさ さと関する実騒的研究, 日本公衛誌，24(1)，13-20 (1976)

12）詫間晋平：新幹線騒音の学習能率に及ぼす影響飞関 する研究, 第21回 日本学校保健学会講演集, 406 (1975)

13）柴田俊忍：新幹線公害の生活環境《及ほす影響次 いて，公害と対策，12(2)，163-172（1976）

14）岩本美江子, 他：山陽新幹線騷音の影響问関する研 究, 日本公衛誌，24(2)，51-71（1977）

15）柴田俊忍：13）と同じ

16）相沢 龍, 他：深夜都市騒音の睡眠に及ほす影響 （第 3 報）道路幅員からみた深夜都市騒音, 日本公衛 誌, 18(4), 291-296 (1971) 